\title{
Effects of Online Cooperative Learning on Motivation in Learning Korean as a Foreign Language
}

\author{
Hiroki Yoshida, Seiji Tani, Tomoko Uchida, Jitsuko Masui, and Akira Nakayama
}

\begin{abstract}
Previous studies highlight positive effects of cooperative learning on language learning motivation. Many attempts have been made to implement cooperative leaning in language classes. Now with the use of computer-mediated communications tools, language learners can learn cooperatively online, out of class. Online cooperative learning provides language learners to communicate with native speakers of their target language, and leads to enhance their motivation in language learning. This study purposed to examine the effects of online cooperative learning on language learners' motivation in KFL. Results indicate that online cooperative learning promotes learners' intrinsic motivation in KFL.
\end{abstract}

Index Terms-Cooperative learning, intrinsic motivation, Korean as a foreign language, online learning.

\section{INTRODUCTION}

Cooperative learning has been implemented in many classes in order to enhance active interaction among the learners. Cooperative learning according to Johnson and Johnson [1] is defined as "the instructional use of small groups so that students work together to maximize their own and each other's learning." Effective cooperative learning requires 1) positive interdependence, 2) individual accountability, 3) promotive interaction, 4) social skills, and 5) group processing [2], [3]. When these elements are well structured into the learning process, cooperative learning leads to increase not only learners' academic performance, but also their participation, responsibility [4], basic needs, and intrinsic motivation [5].

Using synchronous and asynchronous computer-mediated communication tools, cooperative learning is now possible online. Internet-based cooperative learning enables learners who are far away from each other collaborate/cooperate and achieve a common goal. Furthermore, Bliss and Lawrence [6], [7] have reported that computer-mediated cooperative learning resulted in significant increase of student participation, frequency of interaction, and the quality of students' conversation. With the use of computer-mediated communication tools in cooperative learning, educators can provide their learners 1) task-based interaction [8], [9], 2) opportunities to acquire cooperative learning strategies and skills [10]-[12], and 3) authentic and meaningful learning environments [13], [14].

Manuscript received October 10, 2013; revised January 4, 2014. This work was supported by JSPS KAKENHI Grant Number 23520749.

Hiroki Yoshida, Seiji Tani, and Jitsuko Masui are with Tokoha University, Shizuoka, Japan (e-mail: h-yoshida@av-lab.org).

Uchida Tomoko is with Jeju National University, Jeju, Korea.

Akira Nakayama is with Ehime University, Matsuyama, Japan.
Many studies have shown the impact of cooperative learning in language classes. Studies have shown the effects of cooperative learning on language learners' academic achievements such as grammar achievement [15], reading [12], [16]-[18], and writing [19]. It has also been noted that cooperative learning positively affects language learners' motivation [18], [20], [21].

Japanese students' motivation in foreign/second language learning has been recognized as one of the key factors that determine learners' behavior and achievement. Horino and Ichikawa [22] explored the relationship between language learning motives and strategies in high-school students and found that content-attached motives have a significant effect on cognitive strategies such as organization, elaboration, and rehearsal strategies. Kubo [23] advanced Horino and Ichikawa's study and revealed that language learning motives affect learners' behavior in EFL.

In the field of learning Korean as a foreign language (hereinafter referred to as KFL), however, the impact of computer-mediated cooperative learning on motivation has remained under-explored. Therefore, this study aims to identify the effects of online asynchronous cooperative learning on learners' motivation in KFL.

\section{PURPOSE}

The purpose of this study is to identify the effects of online cooperative learning on Japanese university students' motivation in KFL. The research question to be addressed in this paper is: What effects does online cooperative learning have on Japanese university students' motivation in KFL?

All of the participants in this study had never learned Korean language before they entered college. Most of the students had interest in Korean language and culture, but they could take Korean classes only once a week and they didn't have any native Korean teachers in their university. Furthermore, there are only about six thousand Korean people in Shizuoka, Japan in which the students live [24]. So the students did not have many opportunities to communicate with Koreans and/or to contact with Korean culture. Therefore, we aimed to provide the participants an opportunity to communicate with Korean people of their age.

\section{Methodology}

The study was conducted from October, 2012 to December, 2012 , with the purpose of identifying the effects of online cooperative learning on KFL learners' motivation.

\section{A. Participants}

The participants were 24 Japanese first-year university 
students who participated in Korean language classes. The participants experienced project-based cooperative learning via the Internet with Korean university students who study in Jeju, Korea. During the Internet-based cooperative learning session, participants worked in a group of five students: two or three Japanese students and two or three Korean students.

\section{B. Questionnaire}

Participants completed a questionnaire that assesses their motivation in KFL. The questionnaire consists of 24 questions on a 4-point Likert scale ranging from 1 (strongly disagree) to 4 (strongly agree). The questions were made by reference to language learning motivation scales developed by Lim [25], Chan [26], Nuibe [27], Narita [28], and Kobayashi [29]. The 24 questions were:

\section{I am learning Korean because:}

1) Korean language is popular in Japan.

2) I want to be superior in grades in Korean.

3) It will be useful for my future career.

4) Korean is one of the international auxiliary languages.

5) I want to work with Korean language in the future.

6) I want to be considered a cultured person.

7) I am interested in Korean language study itself.

8) I am interested in Korean films and television programs.

9) I want to enjoy Korean songs.

10) I am interested in Korean literature and history.

11) I enjoy studying Korean language.

12) I want to read and write Korean articles.

13) I want to speak in Korean.

14) I want to broaden my perspective.

15) I want to be friendly with Korean people.

16) I have a Korean friend.

17) I want to write letters and e-mails to Korean people.

18) I want to communicate with Korean people.

19) I am interested in Korean people's life style.

20) I want to travel in Korea.

21) Korean is an easy language to start.

22) I simply want to learn another language.

23) My parent(s)/teacher(s) urge me to learn Korean.

24) My friend(s) urge me to learn Korean.

\section{Groupware}

In this study, Yahoo! Groups was applied as the groupware for cooperative learning. Yahoo! Groups was determined to be used because Yahoo! is the most popular portal site in Japan [30], and Yahoo! Groups can be accessed and used not only from PCs but also from cell phones. Additionally, Yahoo! Groups has a briefcase function so the students could exchange and/or share digital files. However, Yahoo! Groups does not have an instant messaging service/function or a chatting service/function. So the participants in Japan and Korea communicated asynchronously using mailing lists and electronic bulletin boards.

\section{Procedure}

The participants first got lectured about the learning objectives and tasks of the Internet-based cooperative learning activity they were to experience with university students in Korea. Then, participants were demonstrated and taught how to operate the groupware Yahoo! Groups which they were to use during the cooperative learning session.
After the demonstration of the system, participants answered to a questionnaire on their motivation in KFL.

During the cooperative learning session, firstly, the Japanese students and Korean students discussed and decided what topic they want to talk about and study. Topics such as "Fashion trends in Japan and Korea," "College life in Japan and Korea," "Working part-time in Japan and in Korea," and "Japanese and Korean people's views of marriage" were adopted. Secondly, the participants explained the actual conditions in their countries. Then, the participants conducted a survey on each topic and exchanged their findings. Lastly, they exchanged impressions and ideas, drew conclusions about the topic, and wrote research reports. While the participants learned cooperatively, teachers facilitated creative conversation and provided students technical support. All of the participants' comments and teachers' comments were stored online.

After the cooperative learning session, the participants answered to a questionnaire on their motivation in KFL again.

\section{RESUlts}

All of the participants completed a questionnaire survey that was conducted before and after the online learning session. This means that the response rate was 100.00 percent. Hereinafter, the results of the 24 answers will be introduced.

\section{A. Participants' Profile}

Table I shows the breakdown of participants by gender, and their experience of communicating with Koreans.

TABLE I: PROFILE OF PARTICIPANTS

\begin{tabular}{|c|c|c|c|}
\hline \multicolumn{2}{|c|}{ Profile of participants } & \multirow{2}{*}{$\frac{\text { Frequency }}{3}$} & \multirow{2}{*}{$\frac{\%}{12.50 \%}$} \\
\hline & Male & & \\
\hline & Female & 21 & $87.50 \%$ \\
\hline & Total & 24 & \\
\hline \multirow{3}{*}{$\begin{array}{l}\text { Experience of } \\
\text { communicating with } \\
\text { Koreans }\end{array}$} & Yes & 7 & $29.17 \%$ \\
\hline & No & 17 & $70.83 \%$ \\
\hline & Total & 24 & \\
\hline \multirow{3}{*}{$\begin{array}{l}\text { Possession of a personal } \\
\text { computer }\end{array}$} & Yes & 12 & $50.00 \%$ \\
\hline & No & 12 & $50.00 \%$ \\
\hline & & 24 & \\
\hline \multirow{5}{*}{$\begin{array}{l}\text { Frequency of computer } \\
\text { use }\end{array}$} & Everyday & 3 & $12.50 \%$ \\
\hline & 3-4 times a week & 7 & $29.17 \%$ \\
\hline & 1-2 times a week & 7 & $29.17 \%$ \\
\hline & Seldom & 7 & $29.17 \%$ \\
\hline & Total & 24 & \\
\hline
\end{tabular}

Nearly 90 percent of the participants were women. The reason for the large proportion of the women is that all of the participants were language learners who major in foreign studies. More than 70 percent of the participants mentioned that they have never communicated with Korean people before. Personal computer ownership was 50.00 percent which is relatively low compared with the penetration rate of computers in Japan which is 77.3 percent as of March, 2012 
[31]. Only 12.50 percent of the participants replied that they use computers every day, and 29.17 percent said that they seldom use computers.

TABLE II: PARTICIPANTS’ MOTIVATION IN KFL

\begin{tabular}{|c|c|c|}
\hline Items & $\begin{array}{l}\text { Pre, } \\
\text { mean } \\
(\mathrm{SD})\end{array}$ & $\begin{array}{l}\text { Post, } \\
\text { Mean } \\
\text { (SD) }\end{array}$ \\
\hline 1. Korean language is popular in Japan. & $\begin{array}{r}2.83 \\
(0.55)\end{array}$ & $\begin{array}{r}2.75 \\
(0.53)\end{array}$ \\
\hline 2. I want to be superior in grades in Korean. & $\begin{array}{r}3.00 \\
(0.78)\end{array}$ & $\begin{array}{r}3.00 \\
(0.78)\end{array}$ \\
\hline 3. It will be useful for my future career. & $\begin{array}{r}3.00 \\
(0.51)\end{array}$ & $\begin{array}{r}2.96 \\
(0.62)\end{array}$ \\
\hline $\begin{array}{l}\text { Korean is one of the international auxiliary } \\
\text { languages. }\end{array}$ & $\begin{array}{r}2.54 \\
(0.59)\end{array}$ & $\begin{aligned} 2.46 \\
(0.66)\end{aligned}$ \\
\hline $\begin{array}{l}\text { I want to work with Korean language in the } \\
\text { future. }\end{array}$ & $\begin{array}{r}2.33 \\
(0.70) \\
\end{array}$ & $\begin{array}{r}2.42 \\
(0.78) \\
\end{array}$ \\
\hline 6. I want to be considered a cultured person. & $\begin{array}{r}2.33 \\
(0.56)\end{array}$ & $\begin{array}{r}2.25 \\
(0.74)\end{array}$ \\
\hline 7. I am interested in Korean language study itself. & $\begin{array}{r}3.08 \\
(1.14)\end{array}$ & $\begin{array}{r}3.46 \\
(0.59)\end{array}$ \\
\hline $\begin{array}{l}\text { 8. I am interested in Korean films and television } \\
\text { programs. }\end{array}$ & $\begin{array}{r}2.83 \\
(1.17)\end{array}$ & $\begin{array}{r}3.38 \\
(0.77)\end{array}$ \\
\hline 9. I want to enjoy Korean songs. & $\begin{array}{r}2.88 \\
(1.12)\end{array}$ & $\begin{array}{r}3.33 \\
(0.76)\end{array}$ \\
\hline 10. I am interested in Korean literature and history. & $\begin{array}{r}2.38 \\
(1.10)\end{array}$ & $\begin{array}{r}2.71 \\
(0.91) \\
\end{array}$ \\
\hline 11. I enjoy studying Korean language. & $\begin{array}{r}2.92 \\
(1.21) \\
\end{array}$ & $\begin{array}{r}3.42 \\
(0.65) \\
\end{array}$ \\
\hline 12. I want to read and write Korean articles. & $\begin{array}{r}3.33 \\
(1.17)\end{array}$ & $\begin{array}{r}3.46 \\
(0.66)\end{array}$ \\
\hline 13. I want to speak in Korean. & $\begin{array}{r}3.25 \\
(1.19)\end{array}$ & $\begin{array}{r}3.67 \\
(0.48)\end{array}$ \\
\hline 14. I want to broaden my perspective. & $\begin{array}{r}3.21 \\
(1.18)\end{array}$ & $\begin{array}{r}3.46 \\
(0.72)\end{array}$ \\
\hline 15. I want to be friendly with Korean people. & $\begin{array}{r}2.88 \\
(1.08)\end{array}$ & $\begin{array}{r}3.13 \\
(0.80)\end{array}$ \\
\hline 16. I have a Korean friend. & $\begin{array}{r}1.54 \\
(0.88)\end{array}$ & $\begin{array}{r}1.83 \\
(0.96)\end{array}$ \\
\hline $\begin{array}{l}\text { 17. I want to write letters and e-mails to Korean } \\
\text { people. }\end{array}$ & $\begin{array}{r}2.17 \\
(0.96)\end{array}$ & $\begin{array}{r}2.50 \\
(0.93)\end{array}$ \\
\hline 18. I want to communicate with Korean people. & $\begin{array}{r}2.67 \\
(1.13) \\
\end{array}$ & $\begin{array}{r}3.42 \\
(0.65) \\
\end{array}$ \\
\hline 19. I am interested in Korean people's life style. & $\begin{array}{r}2.63 \\
(1.06)\end{array}$ & $\begin{array}{r}3.25 \\
(0.79)\end{array}$ \\
\hline 20. I want to travel in Korea. & $\begin{array}{r}3.13 \\
(1.26)\end{array}$ & $\begin{array}{r}3.58 \\
(0.72)\end{array}$ \\
\hline 21. Korean is an easy language to start. & $\begin{array}{r}2.46 \\
(0.82)\end{array}$ & $\begin{array}{r}2.54 \\
(0.78)\end{array}$ \\
\hline 22. I simply want to learn another language. & $\begin{array}{r}2.88 \\
(0.84)\end{array}$ & $\begin{array}{r}2.67 \\
(0.87)\end{array}$ \\
\hline 23. My parent(s)/teacher(s) urge me to learn Korean. & $\begin{array}{r}1.83 \\
(0.75)\end{array}$ & $\begin{array}{r}1.63 \\
(0.71)\end{array}$ \\
\hline 24. My friend(s) urge me to learn Korean. & $\begin{array}{r}1.83 \\
(0.62)\end{array}$ & $\begin{array}{r}1.58 \\
(0.72)\end{array}$ \\
\hline
\end{tabular}

\section{B. Participants' Motivation in KFL}

Before and after learning cooperatively online, the participants were asked why they are learning Korean language.

Table II shows the participants' motivation in KFL. The mean was calculated by giving each of the Likert scale points a number value, where strongly disagree $=1$, disagree $=2$ agree $=3$, and strongly agree $=4$.

\section{Explanatory Factor Analysis}

An exploratory factor analysis was conducted to determine the interrelationships among the questionnaire items. In order to determine the item for each KFL motivation subscale, items that did not load on any factors at $>.35$ were eliminated. As a result, item \#6, \#16, and \#24 were deleted from further analysis. After varimax rotation, a four-factor solution was chosen, accounting for $70.08 \%$ (see Table III). The factors were interpreted: intrinsic motivation (items 7, 8, 9, 10, 11, $12,13,14,15,18,19,20$ ), instrumental motivation (items 4 , 5,17 ), induced motivation (items $21,22,23$ ), and extrinsic motivation (items $1,2,3$ ).

\begin{tabular}{ccccc}
\multicolumn{5}{c}{ TABLE III: FACTORS LOADINGS FOR MOTIVATION IN KFL } \\
\hline \hline No. & Factor 1 & Factor 2 & Factor 3 & Factor 4 \\
\hline Factor I & Intrinsic Motivation & & \\
12. & 0.89 & 0.32 & -0.17 & -0.03 \\
7. & 0.89 & 0.25 & -0.08 & 0.10 \\
14. & 0.84 & 0.38 & -0.10 & 0.08 \\
15. & 0.83 & 0.34 & -0.02 & 0.15 \\
13. & 0.82 & 0.43 & -0.21 & -0.04 \\
9. & 0.81 & 0.13 & 0.19 & 0.20 \\
19. & 0.80 & 0.07 & 0.00 & 0.42 \\
8. & 0.80 & 0.01 & 0.10 & 0.07 \\
11. & 0.70 & 0.23 & -0.48 & 0.21 \\
20. & 0.69 & 0.46 & 0.33 & -0.02 \\
18. & 0.68 & 0.54 & -0.03 & 0.29 \\
10. & 0.57 & 0.06 & -0.54 & -0.06 \\
\hline Factor II & Instrumental Motivation & & \\
4. & 0.24 & 0.73 & -0.29 & 0.10 \\
17. & 0.37 & 0.69 & -0.08 & 0.12 \\
5. & 0.12 & 0.63 & 0.05 & 0.04 \\
\hline Factor III & Induced Motivation & & \\
21. & 0.05 & 0.10 & 0.82 & 0.03 \\
23. & -0.07 & -0.32 & 0.70 & -0.22 \\
22. & 0.29 & -0.08 & 0.46 & 0.42 \\
\hline Factor IV & Extrinsic Motivation & & \\
2. & 0.13 & 0.04 & 0.09 & 0.67 \\
1. & 0.22 & 0.14 & -0.24 & 0.61 \\
3. & -0.47 & 0.18 & -0.07 & 0.52 \\
\hline \hline
\end{tabular}

\section{Effects of Online Cooperative Learning on Motivation in $K F L$}

Effects of online cooperative learning on motivation in KFL were examined by comparing the degree of the increase or decrease of the participants' motivation. For evaluation of the differences, Student's $t$-test was used. The degree of the increase/decrease of motivation was calculated by subtracting the pre-survey motivation scores from the post-survey scores.

Table IV to Table VII show the effects of online cooperative learning on the increase/decrease of participants' motivation in KFL. Results indicate that learners' intrinsic 
motivation in KFL significantly increased by experiencing online cooperative learning $(t(23)=1.98, p<.05)$. However, there was not a significant increase/decrease of the participants' instrumental motivation $(t(23)=1.07$, .05n.s. $)$, induced motivation $(t(23)=1.27$, .05n.s. $)$, and extrinsic motivation $(t(23)=0.50, .05$ n.s. $)$.

TABLE IV: EFFECTS OF ONLINE COOPERATIVE LEARNING ON INTRINSIC MOTIVATION IN KFL

\begin{tabular}{l|r|r|c|c|c}
\hline \hline & $\begin{array}{c}\text { pre, mean } \\
(\mathrm{SD})\end{array}$ & $\begin{array}{c}\text { post, mean } \\
\text { (SD) }\end{array}$ & $d f$ & $t$ & $P$ \\
\hline Intrinsic Motivation & 35.17 & 40.25 & 23 & 1.98 & 0.03 \\
\hline \hline
\end{tabular}

TABLE V: EFFECTS OF ONLINE COOPERATIVE LEARNING ON INSTRUMENTAL MOTIVATION IN KFL

\begin{tabular}{l|r|r|r|r|c}
\multicolumn{6}{c}{ INSTRUMENTAL MOTIVATION IN KFL } \\
\hline \hline & $\begin{array}{c}\text { pre, } \\
\text { mean } \\
(\mathrm{SD})\end{array}$ & $\begin{array}{c}\text { post, } \\
\text { mean } \\
(\mathrm{SD})\end{array}$ & $d f$ & $t$ & $P$ \\
\hline $\begin{array}{l}\text { Instrumental } \\
\text { Motivation }\end{array}$ & 7.04 & 7.38 & 23 & 1.07 & 0.15 \\
\hline \hline
\end{tabular}

TABLE VI: EFFECTS OF ONLINE COOPERATIVE LEARNING ON INDUCED MOTIVATION IN KFL

\begin{tabular}{l|r|r|r|c|c}
\hline & $\begin{array}{c}\text { pre, } \\
\text { mean } \\
(\mathrm{SD})\end{array}$ & $\begin{array}{c}\text { post, } \\
\text { mean } \\
(\mathrm{SD})\end{array}$ & $d f$ & $t$ & $P$ \\
\hline Induced Motivation & $\begin{array}{r}7.17 \\
(1.83)\end{array}$ & $\begin{array}{r}6.83 \\
(1.74)\end{array}$ & 23 & 1.27 & 0.11 \\
\hline \hline
\end{tabular}

TABLE VII: EFFECTS OF ONLINE COOPERATIVE LEARNING ON EXTRINSIC MOTIVATION IN KFL

\begin{tabular}{l|r|r|r|r|r}
\hline \hline & $\begin{array}{c}\text { pre, } \\
\text { mean } \\
(\mathrm{SD})\end{array}$ & $\begin{array}{c}\text { post, } \\
\text { mean } \\
(\mathrm{SD})\end{array}$ & $d f$ & $t$ & $P$ \\
\hline Extrinsic Motivation & 8.83 & 8.71 & 23 & 0.50 & 0.31 \\
& $(1.40)$ & $(1.27)$ & & \\
\hline \hline
\end{tabular}

\section{DISCUSSIONS}

The purpose of the study was to identify the effects of online cooperative learning on Japanese university students' motivation in KFL. In order to gather learners' motivation in KFL, questionnaire surveys were conducted.

Regarding the research question "What effects do online cooperative learning have on Japanese university students' motivation in KFL?" results of questionnaire surveys suggest that Japanese universities students' experience of cooperative learning with Korean university students increased their intrinsic motivation. The results of the study indicate that if Japanese students have an opportunity to learn cooperatively with Korean students and talk about their culture and life styles, they could increase their motivation about learning Korean language and Korean culture. That is to say that the authentic, meaningful, and task-based learning environment which online cooperative learning provides leads to the increase of students' intrinsic motivation in KFL.

\section{CONCLUSION}

The results of the study suggest that Japanese university students' intrinsic motivation in KFL increases by communicating cooperatively and working on authentic and/or meaningful tasks with Korean university students via the Internet. As previously mentioned, participants in this study were all first-year students and they were studying Korean in university classes only once a week. And for most of the students, this was their first chance to communicate with Korean people. With the results that such learners increased their intrinsic motivation, it is suggested that online cooperative learning out of the classroom can promote learners' interest and/or enjoyment in KFL. However, increasing students' motivation is not the goal of foreign language learning. The findings of this study must contribute to develop cooperative learning activities/tasks that enhance learners' motivation and leads to learners' positive behaviors and achievements in KFL. For example, Lim [25] suggests that introducing learners to their interest area promotes their motivation. It is expected that future studies investigate the interaction between cooperative learning activities and tasks with learning motivation in KFL.

Although the findings in this study provide pedagogical implications, they also have a few limitations. Since the participants of this study were Japanese university students who learn Korean language, and were mainly women who are not highly ICT literate, using another sample from elsewhere is required for future generalization.

Moreover, participants in this study used Yahoo! Groups as a groupware for internet-based cooperative learning, and communicated via mailing lists and electronic bulletin boards, which means that participants' communication was primarily text-based and was entirely asynchronous. Therefore, it is recommended that future studies examine the effects of computer mediated communication with voice and/or images, and apply synchronous communication tools such as video-conferencing and chatting.

Given the findings of this study, future study must focus on investigating facilitation techniques and methods to increase learners' motivation in KFL. Previous studies suggest the significance of the role of online facilitators in Internet-based cooperative learning [32]-[37]. Therefore, it is expected to specify the roles and responsibilities of online facilitators with the aim of helping learners who cooperatively learn online increase their motivation in KFL.

\section{REFERENCES}

[1] D. W. Johnson and R. T. Johnson, Learning Together and Alone: Cooperative, Competitive, and Individualistic Learning, Boston, MA: Allyn and Bacon, 1999.

[2] R. T. Johnson and D. W. Johnson, "An overview of cooperative learning," in J. Thousand, A. Villa, and A. Nevin, (Eds), Creativity and Collaborative Learning, Baltimore: P. H. Brookes Press, 1994, pp. 31-44.

[3] D. W. Johnson and R. T. Johnson, "Making cooperative learning work," Theory Into Practice, vol. 38, no. 2, pp. 67-73, 1999.

[4] W. Assinder, "Peer teaching, peer learning: One model," ELT Journal, vol. 45, no. 3, pp. 218-229, 1991.

[5] M. Hanze and R. Berger, "Cooperative learning, motivational effects, and student characteristics: An experimental study comparing cooperative learning and direct instruction in 12th grand physics classes," Learning and Instruction, vol. 17, issue 1, pp. 29-41, 2007.

[6] C. A. Bliss and C. Lawrence, "From posts to patterns: A metric to characterize discussion board activity in online courses," Journal of Asynchronous Learning Networks, vol. 13, no. 2, pp. 15-32, 2009.

[7] C. A. Bliss and B. Lawrence, "Is the whole greater than the sum of its parts? A comparison of small group and whole class discussion board 
activity in online courses," Journal of Asynchronous Learning Networks, vol. 13, no. 4, pp. 25-39, 2009.

[8] A. Finch, "Task-based supplementation: Achieving high school textbook goals through form-focused interaction," English Teaching, vol. 61 , no. $1,2006$.

[9] I. J. Jong, "EFL teachers' perceptions of task-based language teaching: With a focus on Korean secondary classroom practice," Asian EFL Journal, vol. 8, no. 3, pp. 192-206, 2006.

[10] R. E. Slavin, "Research on cooperative learning and achievement: What we know, what we need to know," Contemporary Educational Psychology, vol.21, pp. 43-69, 1996.

[11] B. A. Adeyemi, "Effects of cooperative learning and problem-solving strategies on junior secondary school students' achievement in socia studies," Electronic Journal of Research in Educational Psychology, vol. 6, no. 3, pp. 691-708, 2008.

[12] Z. J. Rahvard, "Cooperative learning strategies and reading comprehension," California Linguistic Notes, vol. 35, no. 2, pp. 1-15, 2010.

[13] S. Kocyigit and R. Zembat, "The effects of authentic tasks on preservice teachers' attitudes towards classes and problem solving skills," Educational Sciences: Theory \& Practice, vol. 13, no. 2, pp. 1045-1051, 2013.

[14] Y. M. Huang, P. S. Chiu, T. Z. Liu, and T. S. Chen, "The design and implementation of a meaningful learning-based evaluation method for ubiquitous learning," Computers \& Education, vol. 57, issue 4, pp. 2291-2302, 2011.

[15] M. R. Ghorbani, "Cooperative language boosts efl students' grammar achievement," Theory and Practice in Language Studies, vol. 2, no. 7, pp. 1465-1471, 2012.

[16] T. A. A. A Odwan, "The effect of the directed reading thinking activity through cooperative learning on English secondary stage students' reading comprehension in Jordan," International Journal of Humanities and Social Science, vol. 2, no. 16, pp. 138-151, 2012.

[17] Y. A. Alshumaimeri and M. M. Almasri, "The effects of using webquests on reading comprehension performance of Saudi EFL students," The Turkish Online Journal of Educational Technology, vol. 11, issue 4, pp. 295-306, 2012.

[18] C. Y. Pan and H. Y. Wu, "The cooperative learning effects on English reading comprehension and learning motivation of EFL freshmen," English Language Teaching, vol. 6, no. 5, pp. 13-27, 2013.

[19] T. Shuhua, L. J. Zhang, and D. Yuanxing, "Integrating cooperative learning into genre-based teaching of EFL writing," CELEA Journal, vol. 32 , no. 1, pp. 99-108, 2009.

[20] F. Abass, "Cooperative learning and motivation," Aichi University Bulletin: Language and Culture, vol. 18, pp. 15-35, 2008.

[21] H. Zhou, "Enhancing non-English majors' EFL motivation through cooperative learning," Procedia Environmental Sciences, vol. 12, pp. 1317-1323, 2012.

[22] M. Horino and S. Ichikawa, "Learning motives and strategies in high-school students' English learning," Japanese Journal of Educational Psychology, vol. 45, pp. 22-29, 1997.

[23] N. Kubo, "Orientation-appraisal model for Japanese university students' learning of English: Relation among learning motive, cognitive appraisal, learning behavior, and performance," Japanese Journal of Educational Psychology, vol. 47, pp. 511-520, 1999.
[24] Multicultural Affairs Division. (2012). Strategic Planning and Public Relations Department, Shizuoka Prefecture. Foreigners in Shizuoka. [Online]. Available: http://toukei.pref.shizuoka.jp/tabunkakyouseika/data/02-050/2012030 1.html

[25] H. Lim and H. J. Kang, "A survey study on the attitude of Korean language and culture learners," Journal of Human Environmental Studies, vol. 5, no. 2, pp. 17-32, 2007.

[26] W. M. Chan and S. W. Chi, "A study of the learning goals of university students of Korean as a foreign language," Electronic Journal of Foreign Language Teaching, vol. 7, no. 1, pp. 125-140, 2010.

[27] Y. Nuibe, F. Kano, and K. Ito, "International survey on university student motivation: In case of Victoria university in New Zealand," Japanese Education, vol. 86, pp. 162-172, 1995.

[28] T. Narita, "Relation between Japanese learning motivation and achievement: With focus on university students from Thailand," Japanese-language Education around the Globe, vol. 8, pp. 1-11, 1998.

[29] A. Kobayashi, "Relation between willingness to communicate in Japanese and learning motive," Bulletin of the Graduate School of Education, Hiroshima University. Part. II, Arts and science education, vol. 57, pp. 245-253, 2008.

[30] GA-Pro. The domestic share of search engines and portal sites. [Online]. Available: http://www.webcreate.ga-pro.com/search.html

[31] Economic and Social Research Institute, Cabinet Office, Government of Japan, "Monthly consumer confidence survey covering all of Japan March 2012," Cabinet Office, 2012.

[32] M. Coghlan, "E-moderation - managing a new language?" presented at Net Working Conference 2001

[33] G. Kemshal-Bell. (2001). The on-line teacher, final report prepared for the project steering committee of the VET teacher and on-line learning project. ITAM. ESD. TAFENSW. [Online]. Available: http://cyberteacher.onestop.net/final per cent20report.pdf

[34] M. M. Lynch, The On-line Educator-A Guide to Creating the Virtual Classroom, London: Routledge, 2002.

[35] Australian Flexible Learning Network (AFLN). (2003). Effective on-line facilitation. Australian Flexible Learning Quick Guide Series. [Online]. Available: http://flexiblelearning.net.au,

[36] G. Packham, P. Jones, C. Miller, and B. Thomas. "Perceptions of effective e-moderation: A tutors viewpoint." in Proc. the Networked Learning Conference, 2004.

[37] G. Packham, P. Jones, B. Thomas, and C. Miller, "Student and tutor perspectives of on-line moderation," Education and Training, vol. 48 , no. 4, pp. 241-251, 2006

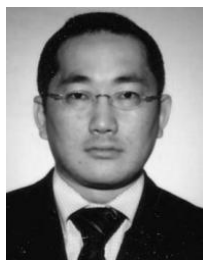

Hiroki Yoshida was born in Nara, Japan in 1973. He received the MEd in educational technology from International Christian University, Japan in 2001. He is currently an associate professor at Tokoha University in Shizuoka, Japan. His research interests include online learning, cooperative learning, hypermedia education, audio-visual education, and teacher education. 